\title{
The Correlation Between Students' Vocabulary Mastery and Their Interest in English Toward Reading Comprehension in Descriptive Text By
}

\author{
Eva Faliyanti \\ English Department of FKIP Muhammadiyah University of Metro \\ Evafaliyanti1980@gmail.com
}

\begin{abstract}
Vocabulary is one aspects in reading comprehension. By having a lot vocabulary, the students understand in reading comprehension. The interest in English also gives effect of students mastery in English. Before the students start to read they are must be interested in English first. Reading is one of skills in English that very essential for the students, because by reading the students can get information from the text. In this research the researcher focoses on reading comprehension in descriptive text. The problems formulation in this research are;(1) How far is the students score of ability in vocabulary mastery toward reading comprehension in descriptive text? (2) How far is the students score of ability in students interest in English toward reading comprehension in descriptive text? (3) How far is the correlation between students' score of vocabulary mastery and students interest in English toward reading comprehension in descriptive text?. The objective of the research are; (1) To identify the students' score in vocabulary mastery toward reading comprehension in descriptive text. (2) To identify the students' score in students interest in English toward reading comprehension in descriptive text. (3) To find out how far the correlation between students' score of vocabulary mastery and students interest in English toward reading compregension in descritive text. Theresearch was conducted at the second semester of Muhammadiyah University Students in Academic Year 2014/2015. The population of this research was 127 students. The researcher used cluster ramdom sampling in taking sample. In collecting the data the researcher used test and questionnarie, namely vocabulary mastery and reading comprehension in descriptive text. In questionnarie used to students interest in English and in analyzing the data, the researcher used Product Moment Formula.After analyzing the data by using the correlation product moment and Regression Linearity Test, the researcher gets the result of based on the calculation, it is found that: 1) of $r=0,45$ ( $X_{1}$ and $Y$ ). 2) $0,61\left(\mathrm{X}_{2}\right.$ and $\left.\left.\mathrm{Y}\right) .3\right) 0,98\left(\mathrm{X}_{1}, \mathrm{X}_{2}\right.$ and $\left.\mathrm{Y}\right)$. The hypothesis can be accepted because $\mathrm{t}_{\text {ratio }}$ $=4,3$ and $t_{\text {daf }}=2,04$. It means that $t_{\text {ratio }}>t_{\text {daf }}$ and $\mathrm{Ha}$ is accepted because there is positif and significant correlation between students' vocabulary mastery and their interest in English toward reading comprehension in descriptive text.
\end{abstract}

Key words: Students' Vocabulary Mastery and Their Interest in English Toward Reading Comprehension Indescriptive Text.

\section{Introduction}

English is regarded as foreign

language in Indonesia which

formally taught in Indonesia from

the primary schools up to university.

Therefore, for the students must be

able master English. It has four basic language skills. They arelistening, speaking, reading, and writing. Beside those skills, there are some components in English namely vocabulary, structure, phonetic/phonology, etc. 
Vocabulary is one of the problems faced by English language. When they have a lot of vocabulary they can understand the English the easily, especially in reading.

The interest in English also gives effect of students mastery in English. Before the students start to read they are must be interested in English first. Because when they do not have interesting in English they difficult to master it. Sometimes, the students are lazy to read. Conseqently, they are getting difficulty to comprehend the text. The students in the second semester have difficulty to understand the text. Because their vocabulary and interest in reading are still low. This is the first time they have the subject specially in reading text. They must focus for this subject. The researcher makes reading texts in which there are some interesting images, for example in the descriptive text. In descriptive text the picture can explain something more interesting and easy to understand.

Based on pre-survey the researcher found that There are 24\%, 7 students who include in low criteria. There are 50\%,16 students who include in high criteria. And they are $26 \%, 8$ students who include in midle criteria. The students are expected to be able to increase their ability especially in vocabulary mastery and their interest in English in order to master reading comprehension in descriptive text well.

\section{CONCEPTUAL DEFINITION}

\section{Students' Vocabulary Mastery}

Handayani (2007,p.1) says that vocabulary is knowledge of word and meaning. The knowledge and word often make the distinction between oral and vocabulary or the word recognize and use in reading and writing. Language consists of a number of words formed. When speak and write uses word. Most of our thinking is in word. Most of communication primarily based on our knowledge of the words.

In other word it can be said that vocabulary is essensial to master. When students want to comprehend the texts, it needs vocabulary. Vocabulary is very important to learn because it is first thing which mastered by learner. 
Yang Zhihong (2000,p.38) says “ Words are the basic unit of language from supports it without vocabulary, one cannot communicate to the effectively or express idea". It means that without having vocabulary mastery, people can not master English. Vocabulary plays a prominent role in mastering English

\section{Students Interest in English}

Another

factorinfluencinglearning

achievementisinterest in learning. Interestcan be definedasthe driving forceof

theinsideandonthesubjecttoperformce rtain activitiesin achievingthe goal.

The intent ofthe statementis themotivation(interest) willcausea change inthe existing energywithin the individual, so thatwill beassociatedwithsymptoms ofpsychiatricorpsychologicalproblem ssomeone, feelingsandemotions, tothenactordo something.

\section{Reading Comprehension}

According to Pakhare (2007,p.173), reading comprehension can be defined level of understanding of a message or text. For formal reading rates (around 200-220 words per minutes) an acceptable level of comprehension is above $75 \%$ )

Based on the definition above, it can be said that reading comprehension is the level of passage or text understanding while reading. Comprehension occurs when readers are able to understand, remember, retell and discuss with others about what they have read. Reading comprehension requires motivation, mental framework for holding ideas, concentration and good study techniques. Good readers employ many strategies as they trying to comprehend what they are reading.

\section{Descriptive Text}

According to Zumarkhin (2005,p.5), descriptive text is to describe something, such as people, thing and animal. Descriptive text is very important for us when the students want to descriptive about something. In addition Kane (2000,p.352) Descriptive text is the description and identification of the structure text such us person and thing.

Meanwhile, Pardiyono (2007,p.33) states that descriptive text is a type of written text. Which has specific function to give 
description about an object (human or non human)

\section{METHODS}

Research design in this research is correlation design, and the researcher uses quantitative method. The research conducted this research at the second semester of Muhammadiyah university students and the research takes 35 students as samples, then to get the data the research uses test. The test is reading comprehension. From a group of students who may give the data on three different variables without giving any treatment and control. The researcher concludes that the research design in this research is correlation design. The researcher only gives the test and questionnaires to the students without having treatment.

\section{FINDINGS}

\section{Analysis of Students Vocabulary}

\section{Mastery}

The vocabulary mastery test was administered in order to look the students' score of students' vocabulary mastery test. The researcher gives 30 items test and the total of the sample were 35 students. Based on the result of the test, the highest score was 93 and the lowest score was 50. The total of all students were 2423 and the average was 69.

\section{Analysis of Students Interest in English}

The interest in English test was administered in order to look the students' score of students interest in English questionnaire. The result of the test can be seen in appendix 36 . The researcher gives 20 items questionnaire and the total of the sample were 35 students. Based on the result of the test, the highest score was 98 and the lowest score is 51. The total of all students were 2554 and the average was 73 .

\section{Analysis of Reading \\ Comprehension in Descriptive}

\section{Text}

The reading comprehension in descriptive text test was administered in order to look the students' score of reading comprehension in descriptive text.The researcher gives 30 items 
and the total of the sample were 35 students. Based on the result of the test, the highest score was 90 and the lowest score was 55 . The total of all students was 2467 and the average is 70.

The Correlation of Students' Vocabulary Mastery (X1)and Reading Comprehension in Descriptive Text(Y)

The researcher knows whether there is positive and significant correlation between students' vocabulary mastery and reading comprehension in descriptive text or not, both variables were calculated by using the formula of person product moment coefficient correlation.

Based on the calculation above found that $\mathrm{r}=0,97$. It means that the correlation between students' vocabulary mastery and reading comprehension in descriptive text is very high based on the table interpretation value $r$.

The Correlation of Students Interest in English (X2) and ReadingComprehension Descriptive Text(Y)
The researcher knows whether there is positive and significant correlation between students interest in English and reading comprehension in descriptive text or not, both variable were calculated by using the formula of person product moment coefficient correlation.

Based on the calculation above, the researcher found that $\mathrm{r}=0,97$. It means that the correlation between students interest in English and reading comprehension in descriptive text is very high based on the table interpretation value $r$.

The Correlation of Students' Vocabulary Mastery(X1) and Students Interest in English(X2)

The researcher knows whether there is positive and significant correlation between students' vocabulary mastery and students interest in English or not, both variable were calculated by using the formula of person product moment coefficient correlation.

Based on the calculation above, the researcher found that $r=0,97$. It means that the correlation between students' vocabulary mastery and students interest in English is very 
high based on the table interpretation value $r$.

\section{Multiple Linearity Test}

To know whether the multiple linear regression that gotten by the researcher is meaningful or not to make conclusion about the correlation between students' vocabulary mastery, interest in English and reading comprehension in descriptive text.

The criteria linearity test is reject $H_{0} \quad f_{\text {ratio }} \geq f_{\text {daf. }}$ Based on the calculation, the researcher found the value of $f_{\text {ratioand }} f_{\text {daf }}$.the researcher found the value in $\mathrm{f}_{\text {ratio }}=136,1$ and the value $\mathrm{f}_{\mathrm{daf}}=3,3$. It means that $f_{\text {ratio }} \geq f_{\text {daf. }}$ So, the researcher concluded that $\mathrm{H}_{\mathrm{o}}$ was rejected and $\mathrm{H}_{1}$ was accepted. So, the multiple linear regression were meaningful to make conclusion.

The Result of Significant Correlation Between Students' Vocabulary Mastery (X1) andReading Comprehension in Descriptive Text (Y)

The researcher found the significant correlation between students' vocabulary mastery (X1) and reading comprehension in descriptive text $(\mathrm{Y})$ by calculating the value of $r_{y 12}$ using the formula as follow :

$$
r_{y 1.2}=\frac{r_{y 1}-r_{y 2} \cdot r_{12}}{\sqrt{\left(1-r_{y 2}{ }^{2}\right)\left(1-r_{12}{ }^{2}\right)}}
$$

After calculating the data, the researcher got score for the significant correlation between $\mathrm{X}_{1}$ and $\mathrm{Y}$. The significant correlation value was 0,45. Based on the $r$ criteria, the significant correlation between $\mathrm{X}_{1}$ and $\mathrm{Y}$ was fair significant.

The Result of Significant Correlation Between Students Interest in English (X2) and Reading Comprehension in Descriptive Text (Y)

The researcher found the significant correlation between students interest in English (X2) and reading comprehension in descriptive text (Y) by calculating the value of $r_{y 21}$ using the formula as follow, after calculating the data, the researcher got score for the significant correlation between $\mathrm{X}_{2}$ and $\mathrm{Y}$. The significant correlation value was 0,61 . Based on the $r$ criteria, the significant correlation between $\mathrm{X}_{2}$ and $\mathrm{Y}$ was high significant. 


$$
r_{y 2.1}=\frac{r_{y 2}-r_{y 1} \cdot r_{12}}{\sqrt{\left(1-{r_{y 1}}^{2}\right)\left(1-r_{12}{ }^{2}\right)}}
$$

The Result of Significant Correlation Between Students' Vocabulary Mastery (X1), Students Interest in English (X2) and Reading Comprehension in Descriptive Text (Y)

The researcher found the significant correlation between students' vocabulary mastery (X1), students interest in English (X2) and reading comprehension in descriptive text $(\mathrm{Y})$ by calculating the value of $\mathrm{r}_{\mathrm{y} 21} \mathrm{using}$ the formula as follow :

$$
R^{2}=\frac{\text { JKreg }}{\sum y^{2}}
$$

After found the data of students' vocabulary mastery (X1), students interest in English (X2) and reading comprehension in descriptive text $(\mathrm{Y})$, the research found the score for the significant correlation between $\mathrm{X} 1, \mathrm{X} 2$, and $\mathrm{Y}$. the researcher got the significant correlation value was 0,98 . Based on the criteria $r$, the significant correlation $\mathrm{X} 1, \mathrm{X} 2$ and $\mathrm{Y}$ was very high.

\section{Coefficient Correlation Test} The Partial Coefficient Correlation Between Students' Vocabulary

\section{Mastery(X1) and Reading Comprehension in Descriptive Text (Y)}

The criteria of the test is Ho if $t_{\text {ratio }} \geq t_{\text {daf }}$, with the probability $\alpha=$ 0,05 . Based on the calculating the researcher found the value of $t_{\text {ratio }}=$ 4,3 and the value of the $t_{d a f}$ with degree of freedom (df) n-k-1 = 2,04. So, the researcher concludes that Ho was rejected and $\mathrm{H}_{1}$ was accepted.

\section{The partial Coefficient Correlation} Between Students Interest inEnglish $\left(\mathbf{X}_{2}\right)$ and reading comprehension in Descriptive Text (Y)

The criteria of the test is Ho if $t_{\text {ratio }} \geq t_{\text {daf }}$, with the probability $\alpha=$ 0,05. Based on the calculating the researcher found the value of $t_{\text {ratio }}=$ 4,3 and the value of the $t_{\text {daf }}$ with degree of freedom $(d f) n-k-1=2,04$. So, the researcher concludes that Ho was rejected and $\mathrm{H}_{1}$ was accepted.

\section{Multiple Coefficient Correlation Between Students' Vocabulary Mastery $\left(\mathbf{X}_{1}\right)$, StudentsInterest in English $\left(\mathbf{X}_{2}\right)$ and Reading Comprehension in Descriptive Text (Y)}

Based on the calculating the data, the researcher found the value 
of $\mathrm{f}_{\text {ratio }}$ is 261,3 and $\mathrm{f}_{\text {daf }} 3,30$. So, the researcher result that $f_{\text {ratio }} \geq f_{\text {daf }}$.based on the test criteria, Ho was rejected and $\mathrm{H}_{1}$ was accepted.

\section{Hypothesis Test}

The significant correlation between the students score in vocabularymastery toward reading comprehension in descriptive text

Based on the calculation above, the researcher found that the correlation between the students score in vocabulary mastery toward reading comprehension in descriptive text was 0,45 . Based on the $r$ criteria, the significant correlation between students' vocabulary mastery toward reading vocabulary mastery was fair significant correlation.

\section{The significant correlation between students' vocabulary mastery, students interest in English and reading comprehension in descriptive text}

Based on the calculation above, the researcher found the score for the significant correlation between students' vocabulary mastery and students interest in English toward reading comprehension in descriptive text, the researcher got the significant correlation value was 0,98 . Based on the criteria $r$, the significant correlation students' vocabulary mastery and students interest in English toward reading comprehension in descriptive text was very high.

\section{Conclusion}

Based on the research objective and result of analysis data in the second semester students of Muhammadiyah University Academic Years of 2014/2015, the researcher draws conclusion as follows:

1. The result of students' score of ability in vocabulary mastery shows significant correlation by increasing score of the students in the research was high score. The students got score 80 in try out and 83 in test. Its means that the students can enough to identifying the vocabulary of family, supermarket and school.

2.The result of students' score of interest in English shows significant correlation by increasing score of the students in the research was high score. The students 90 score in this 
test. Its means that the students can enough to identifying the follow the material well, response about English, lessonIdentify the students effort, identify the students pleasure.

3. The result of students' score of reading comprehension in descriptive text shows significant correlation by increasing score of the students in the research was high score. The students got score 77 in try out and 90 in test. Its means that the students can enough to identifying the identify the main idea, purpose of the text, characteristics of description, characters, generic structure, tense, pronoun, antonym, synonym.

4. The correlation between students' score of vocabulary mastery and students interest in English toward reading comprehension in descriptive text in hypothesis is positive and significant. The statement is supported by result of finding that $r_{\text {countis }} 8$ that $r_{\text {table }} 3,3$ on the significant level of 0,05 . The value of $r_{\text {countwas higher than the value of }}$

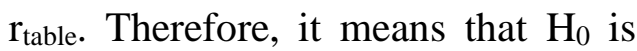
rejected and $H_{a}$ is accepted $\mu_{1} \neq \mu_{2}$ (there is any correlation).
Based on the calculating in the previous chapter, the researcher concludes that the correlation between students' vocabulary mastery and their interest in English toward reading comprehension in descriptive test is any positive and significant correlation. It mean that, by the result of hypothesis of Ho is rejected and Ha is accepted.

\section{REFERENCES}

Handayani.(2007).Look Ahead An English.Jakarta:Erlangga.

Kane. (2000). Definition of descriptive text: New York: The Guilford Paess.

Pakhare. (2007).Reading Comprehension Strategies. New York: The Guilford Press.

Pardiyono. (2007). PastiBisa! Teaching GenreBasedWriting. Jogjakarta: Andi.

Yang Zhihong. (2000). .An Introduction to The Practice of English Language Teaching. Malaysia: Longman.

Zumarkshin.(2005). Descriptive Text inEnglish:http:/www.descripti vetext.com Retrieved on May 25th. 